\title{
Statistical inferences in material selection of a polymer matrix for natural fiber composites
}

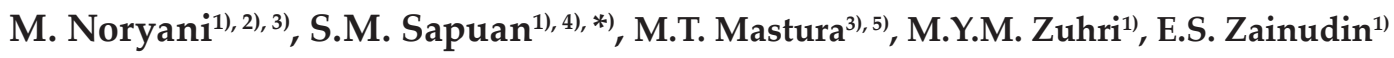 \\ DOI: dx.doi.org/10.14314/polimery.2020.2.4
}

\begin{abstract}
In this paper, statistical inferences in material selection of polymer matrix for natural fiber composite are presented. Hypothesis testing and confidence interval were used to evaluate the suitability of the sample for use as a matrix in natural fiber reinforced composites. The screening process for material selection was carried out using a stepwise regression method. Then, the ranking process in material selection was conducted using an estimation of performance score $(P S)$ for mechanical properties such as impact strength (IS), elongation at break (E) and tensile strength (TS). Ten types of polymer were involved in the study. The final selection revealed that polyamide (PA6), polyurethanes (PUR) and poly propylene (PP) are the potential candidates to manufacture hand-brake levers according to IS, $E$ and $T S$, respectively. Here, it was found that the score for Tp (thermoplastic) is better than Ts (thermoset) in terms of IS. In contrast, the Ts offered a better score result than, Tp, with respect to $E$ and TS. The results of statistical measurements using statistical modelling prove that the data analysis can be used as a part of the decision making in material selection.
\end{abstract}

Keywords: material selection, polymer matrix, stepwise regression, hypothesis testing, confidence interval.

\section{Wnioskowanie statystyczne $w$ wyborze materiału osnowy polimerowej kompozytów z włóknami naturalnymi}

Streszczenie: Opisano wnioskowanie statystyczne dotyczące wyboru materiału osnowy polimerowej kompozytu z włóknami naturalnymi. Testy hipotez statystycznych i przyjęte przedziały ufności służyły do oceny próbki pod względem przydatności do zastosowania w charakterze osnowy polimerowej w kompozycie wzmocnionym włóknem naturalnym. Selekcji materiałów dokonano przy użyciu metody regresji krokowej, następnie uszeregowano wybrane materiały z wykorzystaniem rankingu oceny (PS) właściwości mechanicznych, takich jak: udarność (IS), wydłużenie przy zerwaniu (E) i wytrzymałość na rozciąganie (TS). Wyselekcjonowano wstępnie 10 rodzajów polimerów zaliczanych do grup polimerów termoplastycznych (Tp) i termoutwardzalnych (Ts). Wnioskowanie statystyczne wykazało, że poliamid (PA6), poliuretany (PUR) i polipropylen (PP) są potencjalnie korzystnymi osnowami polimerowymi do wytwarzania dźwigni hamulca ręcznego. Stwierdzono, że polimery z grupy Tp wykazują lepszą udarność niż polimery z grupy Ts. Natomiast materiały Ts charakteryzują korzystniejsze wartości wydłużenia przy zerwaniu i wytrzymałości na rozciąganie niż ich odpowiedniki z grupy Tp. Wyniki przeprowadzonej analizy danych z zastosowaniem modelowania statystycznego dowodzą, że metoda ta może być pomocna przy wyborze materiału odpowiedniego do planowanej aplikacji.

Słowa kluczowe: wybór materiału, osnowa polimerowa, regresja krokowa, testowanie hipotez, przedział ufności.

\footnotetext{
1) Universiti Putra Malaysia, Department of Mechanical and Manufacturing Engineering, Advanced Engineering Materials and Composites Research Centre, 43400 UPM Serdang, Selangor, Malaysia.

2) Universiti Teknikal Malaysia Melaka, Faculty of Mechanical Engineering, Hang Tuah Jaya, 76100 Durian Tunggal, Melaka, Malaysia.

3) Universiti Teknikal Malaysia Melaka, Centre of Advanced Research on Energy, Hang Tuah Jaya, 76100 Durian Tunggal, Melaka, Malaysia.

4) Universiti Putra Malaysia, Institute of Tropical Forestry and Forest Products (INTROP), Laboratory of Biocomposite Technology, 43400 UPM Serdang, Selangor, Malaysia.

5) Universiti Teknikal Malaysia Melaka, Faculty of Mechanical and Manufacturing Engineering Technology, Hang Tuah Jaya, 76100 Durian Tunggal, Melaka, Malaysia.

*) Author for correspondence: sapuan@upm.edu.my
} 
Recent studies discuss the ability of polymer composite to replace metal-based material, especially in the automotive and construction industries. Many researchers have put forward the capabilities, suitability and affordability of natural fibers as reinforcement agents for the polymer matrices. Natural fiber reinforced polymer composites had a good performance score with regard to their physical, mechanical and environmental properties when used in manufacturing automotive components such as clutch pedal, car front hood, buggy bonnet, bumper beam, car roof, brake lever and anti-roll bar [1-7]. As the materials are from natural sources, they can offer an economical outflow, lightweight, environmentally friendly materials and a biodegradable effect [5, 8-13]. However, the poor dimensional stability and high moisture absorption become a problem to these materials [14]. There are many treatments that can increase the strength connection between the natural fiber and polymer matrix [15-19] to produce a valuable polymer composite, especially in the automotive industry. Generally, thermoplastic (Tp) and thermoset (Ts) materials are the polymers used in many applications. Recently, there is a research trend in the automotive industry to produce lightweight vehicles to save energy consumption [20, 21]. Many studies have reported a good connection between natural fiber and polymer matrix based on the chemical composition as a better composite in automotive applications [22-24]. In addition, the combination also provides a balanced score for mechanical, thermal and electrical properties [25-27].

In general, the engineering plastics industry confirms the advantages of the product, such as it is lightweight, transparent, economical to produce, self-lubricates, has low water absorption and good resistance to corrosion, and design flexibility [28-30]. However, Tp and Ts have their own pros and cons. Fast processing, highly recyclable, high impact resistance, chemical resistance and eco-friendly manufacturing are the advantages of Tp. However, generally, Tp is more expansive and melts if heated. In contrast, Ts is more resistant to high temperature, has a highly flexible design, excellent aesthetic appearance, high level of dimensional stability and is cost effective. The disadvantages of Ts are that it is unrecyclable, difficult to surface finish, cannot be remolded or reshaped, and has a lower production rate due to its lengthy cure time [31-33]. In reality, there are variable and inconsistent conclusions about Tp and Ts in different applications. It is known that Tp is tougher than Ts because of the structure of the polymer itself. Chung [34] also claimed that the manufacturing time of Tp is shorter than that of Ts. Another study found that the mechanical properties, such as tensile strength, of Ts are better than those of Tp [35]. Although a number of investigations have reported interesting results for Tp and Ts, no study has examined their performance by using statistical inferences such as hypothesis testing and confidence interval.

In material selection, numerous multi-criteria decision-making (MCDM) tools can be used, such as Analytical
Hierarchy Process, Analytical Network Process, Multiattribute Utility Theory, Preference Selection Index, Technique of Ranking Preferences by Similarity of the Ideal Solution and Quality Function Deployment. In practice, these tools have their own strengths and limitations on screening and ranking methods in the process to select the best material $[36,37]$. The major problem in the conventional MCDM method is inconsistent judgement and preference subjectivity over the process selection. For example, there is no standard measurement for the weighting process in Analytical Hierarchy Process and Analytical Network Process [36, 38]. Some of the tools are only able to deal with qualitative data, which is also an issue in material selection [39]. The final decision is affected by the limitations of these tools. However, a recent study by Noryani et al. [40] introduced a novel statistical framework by using stepwise regression on the screening process. This approach is proven to finalize the best natural fiber in automotive application [41]. Statistical analyzes such as estimation, error analysis, hypothesis testing and confidence interval are the alternative measure-
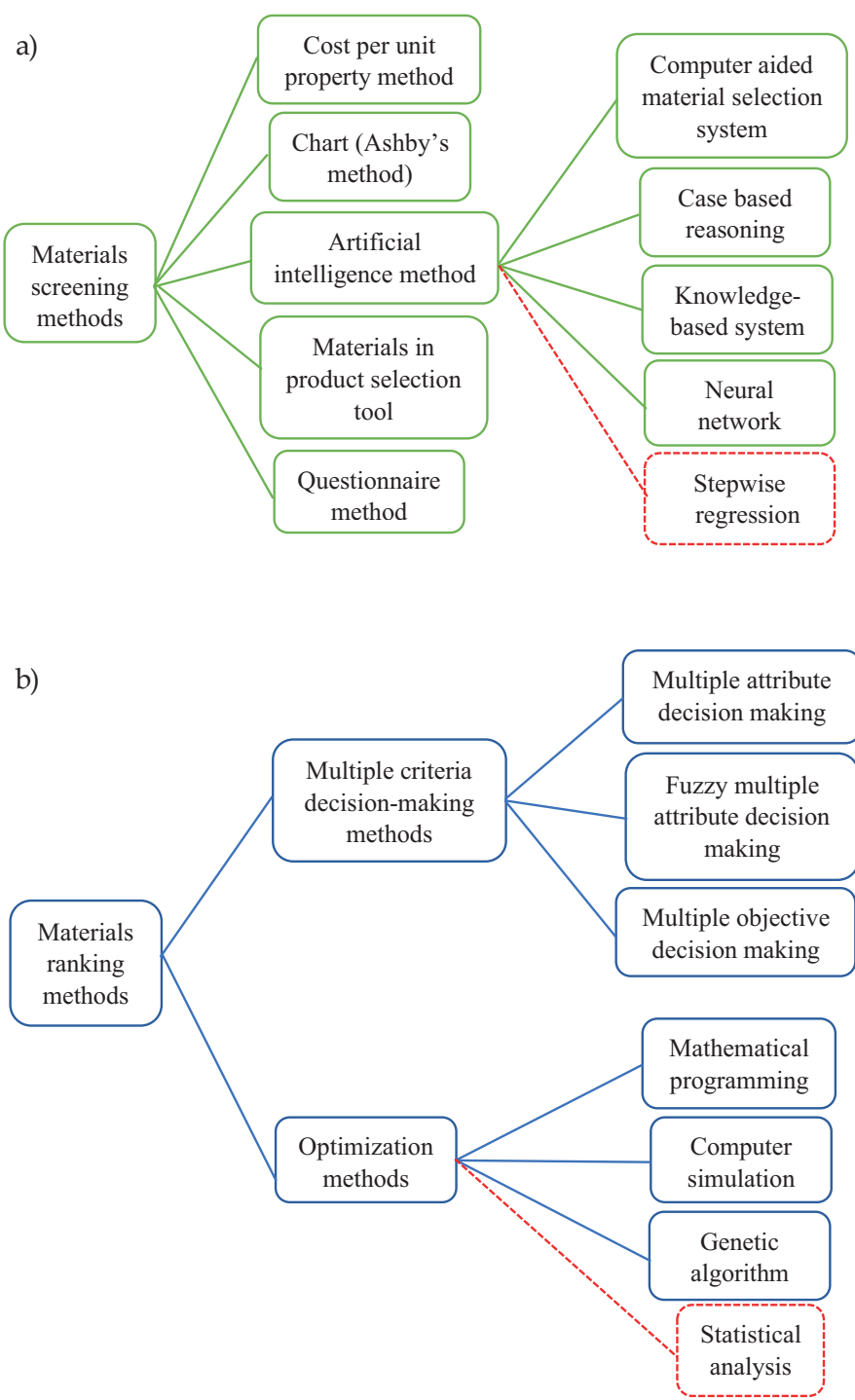

Fig. 1. Classification of: a) screening, b) ranking methods in material selection [37] 
ments in the optimization method to rank the material's performance. In this study, the performance score (PS) is measured by using equation (1), where $x_{i}$ is the mechanical properties of the polymer matrix. This innovative contribution by using statistical inferences in material selection is shown in Fig. 1. To demonstrate the potential of this novel approach to screening and ranking methods as well as its suitability for material selection of the polymer matrix of an automotive component, the stepwise regression of polymer matrix data is studied and the significant statistical model for each polymer matrix is presented. Hypothesis testing and confidence interval are discussed as inferential analysis from the sample to estimate the PS using a constructed statistical model to make the final decision. This approach can give extra information and increase the decision maker's confidence to select the most potential candidate to manufacture a hand-brake lever for car parking, as in the case study.

$$
P S=\sum_{i=1}^{n} x_{i} \quad i=1,2, \ldots, n
$$

\section{EXPERIMENTAL PART}

The improvement using statistical inferential analysis in a statistical framework on previous studies is shown in Fig. 2.

\section{Material selection of Tp and Ts}

The material selection process is an important stage in engineering applications, especially in product development for long-term success [42]. The engineer should select the most suitable material that performs well and can easily be commercialized. To avoid major loss during product design testing, the material selection process is the critical part of the manufacturing process [37]. Moreover, in this study, secondary data about the polymer matrix of thermoplastic and thermoset plastic from previous works is utilised, as shown in Table 1.

All the polymer in this study are hydrophobic polymers because this polymer used natural fiber as the reinforcement agent to the composite. The composite should water resistant in automotive application to increase the strength of the properties. In this case, there are several processes used to prepare this type of polymer, injection molding, extrusion, pultrusion and hand lay-up are the common methods used in research area. This data set is used to select the most suitable polymer to manufacture a hand-brake lever, as shown in Fig. 3, for automotive industry application as the case study.

\section{Statistical measurement}

Mean $(\mu)$ and standard deviation $(\sigma)$ are the normal statistical measurements used in previous studies [49-51]. Here, minimum, middle and maximum values

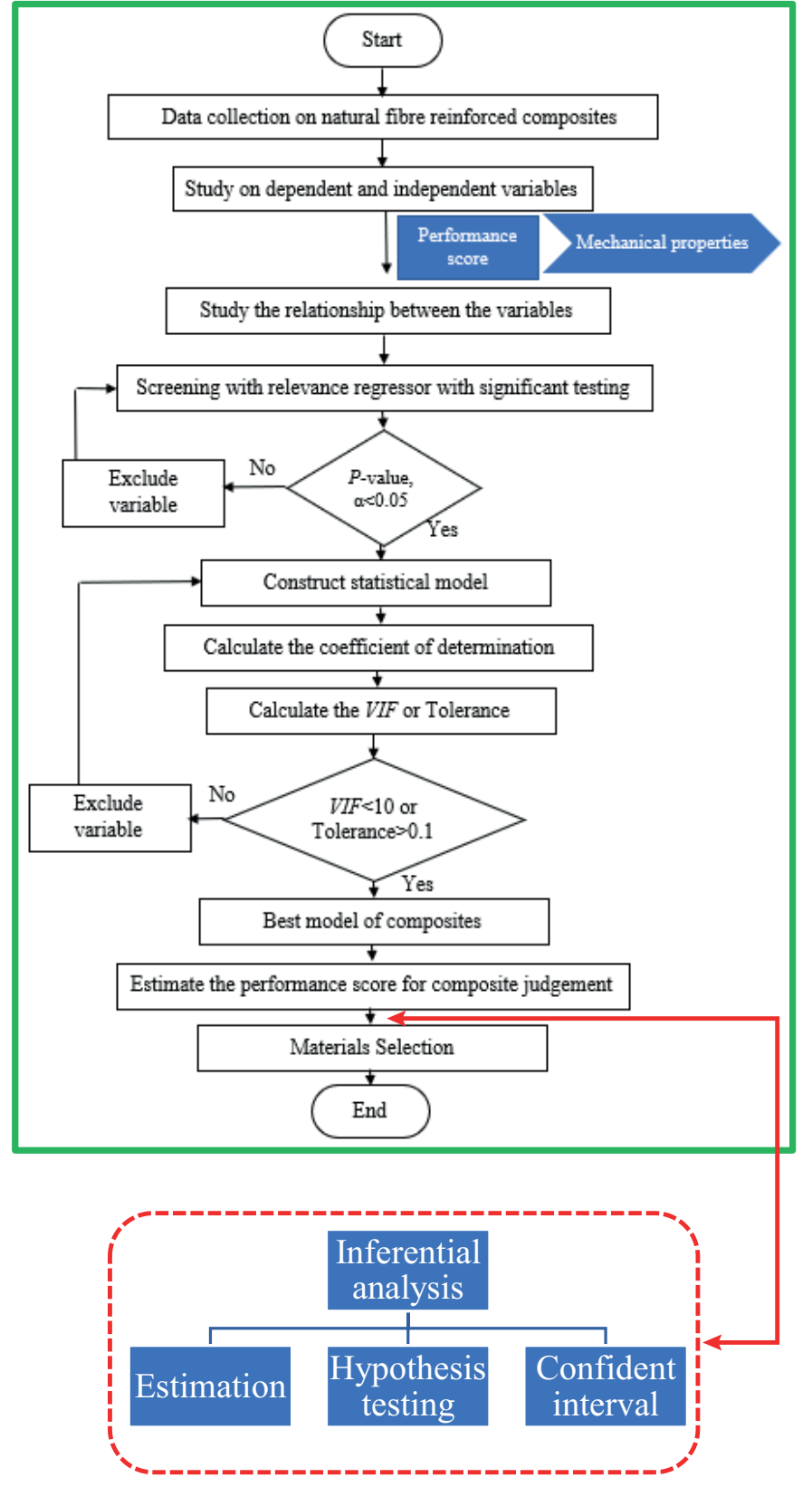

Fig. 2. Additional information for final decision on material selection

are used for mechanical properties of the Tp and Ts. The framework introduced previously by Noryani et al. [40] is used for the screening process, which involves another statistical measurement such as correlation $(r)$, determination of coefficient $\left(R^{2}\right)$, adjusted determination coefficient $\left(A d j R^{2}\right)$ or variance inflation factor (VIF) to identify the best model of the polymer. Then, a comparison between the alternative polymers via an estimation process using statistical modelling is performed. Okayasu et al. [35] mentioned, estimation using statistical analysis can give a better result compare to the compound law. T-test statistics are used in hypothesis testing and confidence interval to confirm the successful inferential analysis to draw a conclusion about the performance of the Tp and Ts. 
T a b 1 e 1 . The properties of thermoplastic and thermosetting $[4,17,30,43-46]$

\begin{tabular}{|c|c|c|c|c|c|c|}
\hline Polymer & $\begin{array}{c}\text { Density }(D) \\
\mathrm{g} / \mathrm{cm}^{3}\end{array}$ & $\begin{array}{c}\text { Young's } \\
\text { modulus, }(Y M) \\
\text { GPa }\end{array}$ & $\begin{array}{c}\text { Tensile } \\
\text { strength, (TS) } \\
\mathrm{MPa}\end{array}$ & $\begin{array}{c}\text { Elongation at } \\
\text { break, }(E) \\
\% \\
\end{array}$ & $\begin{array}{c}\text { Impact } \\
\text { strength, (IS) } \\
\mathrm{J} / \mathrm{m}^{2}\end{array}$ & $\begin{array}{c}\text { Water absorp- } \\
\text { tion, }(W A) \\
24 \text { hours }\end{array}$ \\
\hline PP & $\begin{array}{l}0.86 \\
0.89 \\
0.90 \\
0.91 \\
0.92\end{array}$ & $\begin{array}{l}0.95 \\
1.36 \\
1.40 \\
1.60 \\
1.80\end{array}$ & $\begin{array}{l}26.0 \\
33.7 \\
34.5 \\
36.0 \\
41.4\end{array}$ & $\begin{array}{c}15.0 \\
43.0 \\
58.1 \\
73.2 \\
100.0\end{array}$ & $\begin{array}{c}24.40 \\
85.05 \\
145.70 \\
206.35 \\
267.00\end{array}$ & $\begin{array}{c}0.010 \\
0.010 \\
0.015 \\
0.02 \\
0.02\end{array}$ \\
\hline PS & $\begin{array}{l}1.04 \\
1.04 \\
1.05 \\
1.06 \\
1.06\end{array}$ & $\begin{array}{l}3.14 \\
3.57 \\
4.00 \\
4.50 \\
5.00\end{array}$ & $\begin{array}{l}25.0 \\
38.1 \\
51.1 \\
60.1 \\
69.0 \\
\end{array}$ & $\begin{array}{l}12.0 \\
16.5 \\
21.0 \\
23.0 \\
25.0\end{array}$ & $\begin{array}{l}1.0 \\
1.1 \\
1.0 \\
1.1 \\
1.0 \\
\end{array}$ & $\begin{array}{l}0.03 \\
0.04 \\
0.06 \\
0.08 \\
0.10\end{array}$ \\
\hline HDPE & $\begin{array}{l}0.94 \\
0.95 \\
0.96 \\
0.96 \\
0.97\end{array}$ & $\begin{array}{l}0.40 \\
0.76 \\
0.95 \\
1.00 \\
1.50\end{array}$ & $\begin{array}{l}14.5 \\
22.0 \\
26.3 \\
32.0 \\
38.0\end{array}$ & $\begin{array}{c}200 \\
745 \\
1000 \\
1120 \\
1290\end{array}$ & $\begin{array}{c}26.7 \\
288 \\
548 \\
808 \\
1068\end{array}$ & $\begin{array}{l}0.01 \\
0.01 \\
0.02 \\
0.02 \\
0.01 \\
\end{array}$ \\
\hline LDPE & $\begin{array}{l}0.91 \\
0.92 \\
0.93 \\
0.93 \\
0.94 \\
\end{array}$ & $\begin{array}{l}0.06 \\
0.14 \\
0.22 \\
0.31 \\
0.38\end{array}$ & $\begin{array}{c}7 \\
17 \\
40 \\
43 \\
78 \\
\end{array}$ & $\begin{array}{l}100 \\
375 \\
650 \\
675 \\
700 \\
\end{array}$ & $\begin{array}{c}854 \\
900 \\
930 \\
950 \\
1000 \\
\end{array}$ & $\begin{array}{l}0.015 \\
0.010 \\
0.015 \\
0.010 \\
0.015\end{array}$ \\
\hline TPU & $\begin{array}{l}1.12 \\
1.15 \\
1.18 \\
1.21 \\
1.24 \\
\end{array}$ & $\begin{array}{l}1.31 \\
1.50 \\
1.69 \\
1.88 \\
2.07\end{array}$ & $\begin{array}{l}31.0 \\
38.8 \\
46.5 \\
54.3 \\
62.0 \\
\end{array}$ & $\begin{array}{c}60 \\
182.5 \\
305 \\
427.5 \\
550\end{array}$ & $\begin{array}{c}9.42 \\
16.80 \\
24.21 \\
31.60 \\
39.00\end{array}$ & $\begin{array}{l}0.15 \\
0.16 \\
0.17 \\
0.18 \\
0.19 \\
\end{array}$ \\
\hline PA6 & $\begin{array}{l}1.120 \\
1.125 \\
1.130 \\
1.135 \\
1.140 \\
\end{array}$ & $\begin{array}{l}2.80 \\
2.85 \\
2.90 \\
2.95 \\
2.90 \\
\end{array}$ & $\begin{array}{l}35 \\
39 \\
43 \\
61 \\
79 \\
\end{array}$ & $\begin{array}{c}38.8 \\
59 \\
80 \\
100 \\
120 \\
\end{array}$ & $\begin{array}{c}42.7 \\
72 \\
101 \\
130.5 \\
160 \\
\end{array}$ & $\begin{array}{l}1.30 \\
1.43 \\
1.55 \\
1.68 \\
1.80 \\
\end{array}$ \\
\hline PR & $\begin{array}{l}1.2 \\
1.3 \\
1.4 \\
1.4 \\
1.5\end{array}$ & $\begin{array}{l}2.0 \\
2.5 \\
3.3 \\
3.9 \\
4.5\end{array}$ & $\begin{array}{c}40 \\
52.5 \\
65 \\
77.5 \\
90\end{array}$ & $\begin{array}{c}2 \\
2.2 \\
2.4 \\
2.5 \\
2.6\end{array}$ & $\begin{array}{c}15 \\
91 \\
167 \\
243 \\
320 \\
\end{array}$ & $\begin{array}{l}0.10 \\
0.15 \\
0.20 \\
0.25 \\
0.30\end{array}$ \\
\hline VE & $\begin{array}{l}1.20 \\
1.25 \\
1.30 \\
1.35 \\
1.40 \\
\end{array}$ & $\begin{array}{l}3.10 \\
3.27 \\
3.45 \\
3.62 \\
3.80 \\
\end{array}$ & $\begin{array}{c}69 \\
72.5 \\
76 \\
79.5 \\
83\end{array}$ & $\begin{array}{l}4.0 \\
4.7 \\
5.5 \\
6.2 \\
7.0 \\
\end{array}$ & 250 & $\begin{array}{l}0.10 \\
0.05 \\
0.10 \\
0.15 \\
0.20\end{array}$ \\
\hline ER & $\begin{array}{l}1.10 \\
1.20 \\
1.25 \\
1.30 \\
1.40\end{array}$ & $\begin{array}{l}3.0 \\
3.7 \\
4.5 \\
5.2 \\
6.0\end{array}$ & $\begin{array}{c}35 \\
51 \\
67 \\
83 \\
100\end{array}$ & $\begin{array}{l}1.0 \\
2.5 \\
3.5 \\
4.7 \\
6.0\end{array}$ & $\mathrm{n} / \mathrm{a}$ & $\begin{array}{l}0.10 \\
0.20 \\
0.25 \\
0.30 \\
0.40\end{array}$ \\
\hline PUR & $\begin{array}{l}1.04 \\
1.06 \\
1.09 \\
1.10 \\
1.13\end{array}$ & $\begin{array}{l}4.09 \\
4.15 \\
4.20 \\
4.25 \\
4.30\end{array}$ & $\begin{array}{c}14 \\
39 \\
52 \\
69 \\
75.8\end{array}$ & $\begin{array}{c}3.0 \\
4.5 \\
6.0 \\
8.0 \\
10.0\end{array}$ & $\mathrm{n} / \mathrm{a}$ & $\begin{array}{l}0.10 \\
0.10 \\
0.15 \\
0.20 \\
0.20\end{array}$ \\
\hline
\end{tabular}

PP: polypropylene, PS: polystyrene, HDPE: high-density polyethylene, LDPE: low-density polyethylene, TPU: thermoplastic polyurethane, PA6: polyamide, PR: polyester resin, VE: vinyl ester resin, ER: epoxy resin, PUR: polyurethanes.

\section{Hypothesis testing and confidence interval}

Hypothesis testing is one of the inferential statistics that can be used to make a conclusion about the population based on a sample. In this study, hypothesis testing is used to verify the performance of Tp and Ts. There are five command steps in hypothesis testing, which are: write the null and alternative hypothesis, perform the statistics testing, find the critical point and decide the region, finalise the decision making and, lastly, make a con- 
a)

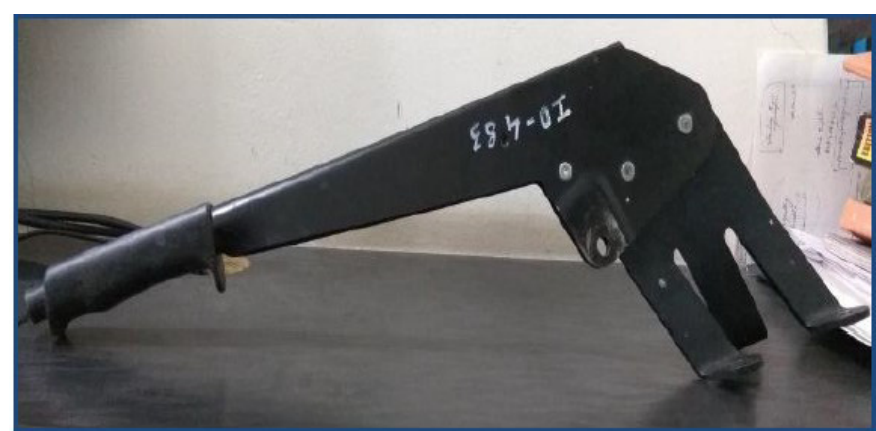

b)

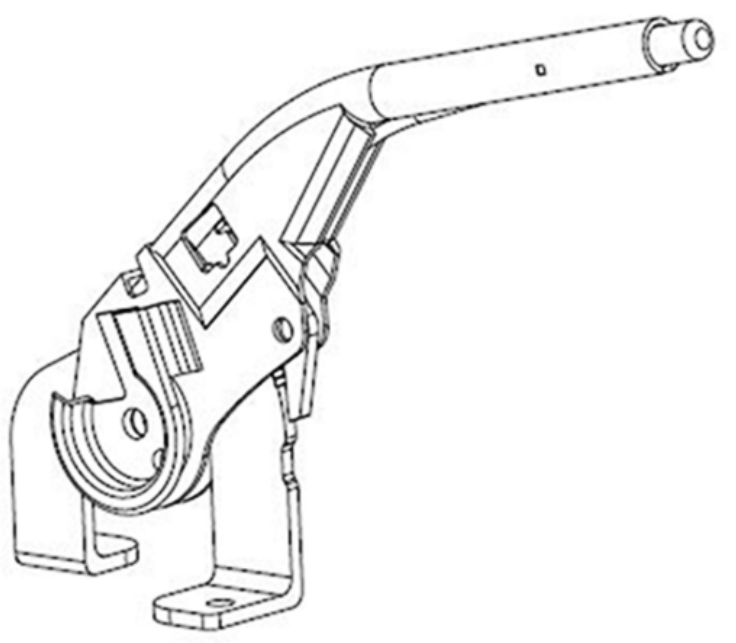

Fig. 3. Example of a hand-brake lever for: a) Suzuki Maruti, b) Proton Wira $[47,48]$

clusion. All the calculations and conclusions in this study are based on $\alpha=0.05$ ( $5 \%$ standard error) significant value and $95 \%$ confidence interval. The one-tailed test is used where the hypothesis condition shows that $\mathrm{Tp}$ is better than Ts. Otherwise, the conclusion is that Ts perform better than Tp. Equations (2) to (4) are used to perform the hypothesis testing and confidence interval.

$$
\begin{gathered}
t=\frac{\left(\bar{x}_{\mathrm{Tp}}-\bar{x}_{\mathrm{Ts}}\right)-\left(\mu_{\mathrm{Tp}}-\mu_{\mathrm{Ts}}\right)}{S_{\bar{x}_{\mathrm{Tp}}-\bar{x}_{\mathrm{Ts}}}} \\
\mu=\left(\bar{x}_{\mathrm{Tp}}-\bar{x}_{\mathrm{Ts}}\right) \pm t_{\alpha} S_{\overline{\mathrm{T}}_{\mathrm{Tp}}-\bar{x}_{\mathrm{Ts}}}=\bar{x} \pm t_{\alpha} S_{P} \sqrt{\frac{1}{n_{\mathrm{Tp}}}+\frac{1}{n_{\mathrm{Ts}}}} \\
S_{P}=\sqrt{\frac{\left(n_{\mathrm{Tp}}-1\right) S_{\mathrm{Tp}}^{2}+\left(n_{\mathrm{Ts}}-1\right) S_{\mathrm{Ts}}^{2}}{n_{\mathrm{Tp}}+n_{\mathrm{Ts}}-2}}
\end{gathered}
$$

where: $\bar{x}_{\mathrm{Tp}}$ - sample mean of Tp properties, $\bar{x}_{\mathrm{Ts}}-$ sample mean of Ts properties, $\mu_{\mathrm{Tp}}$ - population mean of Tp properties, $\mu_{\mathrm{Ts}}$ - population mean of Ts properties, $S_{\mathrm{Tp}}$ - standard deviation of Tp, $S_{\mathrm{Ts}}$ - standard deviation of Ts, $S_{\mathrm{p}}-$ pooled standard deviation for two samples, $n_{\mathrm{Tp}}$ - number of samples for Tp, $n_{\mathrm{Ts}}-$ number of samples for Ts.

\section{RESULTS AND DISCUSSION}

\section{Best model of polymer matrix using stepwise regression}

Table 2 shows the best statistical model with significant mechanical properties with an excellent $A d j R^{2}$ that described the variation of $P S$. This variation is explained by the significant mechanical properties. For example, the third model proposed by stepwise regression for PP mentioned that $99.9 \%$ of the variation of PS is explained by IS, $E$ and TS. This new approach was proposed in a previous study by Noryani et al. [40] to select the natural fiber composite. Another previous study reported significant tensile and flexural properties of a kenaf reinforced polypropylene composite using stepwise regression [52]. In this paper, the only significant mechanical property for thermosetting PR was WA, while the other mechanical properties did not contribute to the model for estimation purposes. Each polymer has its own significant mechanical properties. For estimation purposes, the most significant mechanical properties equation of the polymer where IS, $E$ and TS are chosen to be compared in the selection process. For example, IS is the significant mechanical property for PP, HDPE, LDPE and PA6. Therefore, this model is used to estimate the PS by substituting the product design specification of IS in manufacturing the hand-brake lever. The process is also applied for $E$ and TS for the alternative polymer. The quality of the material's interface strength is evaluated by using an estimation process through the statistical model [53].

\section{Material selection based on performance of mechanical properties}

IS, E and TS are the most significant mechanical properties in the polymer model. Here, the product design specification for manufacturing a hand-brake lever of IS, E and TS is referred $[43,48,54]$. Selection of the materials should be consistent with the industry declaration on product design specification [38]. One of the materials used to manufacture the hand-brake lever is structural steel S235 [48]. The properties of S235 for IS, E and TS are $27 \mathrm{~J} / \mathrm{m}^{2}, 25 \%$ and $460 \mathrm{MPa}$, respectively. Figures 4, 5 and 6 show the PS score according to IS, E and TS. From the result, the PA6 is the best material to manufacture the hand-brake lever, if the focus of the automotive industry for the component is on IS. Surprisingly, PP, HDPE and LDPE only score around 26 to 27 of PS compared to PA6, which scored 61.61. Based on Fig. 5, there are six polymers involved in estimation on PS according to elongation at break of that material. This score can show the capability of a material to maintain its shape without crack formation. Both thermoset plastics, which are PUR (31.12) and ER (29.28), score the highest for PS compared to the other thermoplastic. In Fig. 6, the thermoplastic materials such as PP (512.48), PS (509.57) and HDPE (501.48) perform better on PS (according to TS) com- 
T a b l e 2. The best model with significant mechanical properties using stepwise regression

\begin{tabular}{|c|c|c|c|c|c|c|c|}
\hline Polymer & Model & $\begin{array}{l}\text { Mechanical } \\
\text { properties }\end{array}$ & $R^{2}$ & $\operatorname{Adj} R^{2}$ & $\begin{array}{l}\text { Standard } \\
\text { error }\end{array}$ & $P$-value & Equation \\
\hline \multirow{3}{*}{$\mathrm{PP}$} & 1 & IS & 0.999 & 0.998 & 6.625 & 0.000 & $y=37.96+1.388 I S$ \\
\hline & 2 & $I S, E$ & 1.0 & 0.999 & 0.701 & 0.000 & $y=23.658+0.905 I S+1.465 E$ \\
\hline & 3 & $I S, E, T S$ & 1.0 & 0.999 & 0.034 & 0.000 & $y=-0.8798+1.009$ IS $+0.965 E+1.116$ TS \\
\hline \multirow{2}{*}{ PS } & 1 & TS & 1.0 & 0.999 & 0.512 & 0.000 & $y=9.04+01.342 T S$ \\
\hline & 2 & $T S, E$ & 1.0 & 0.999 & 0.074 & 0.000 & $y=4.945+1.097$ TS $+0.822 E$ \\
\hline \multirow{3}{*}{ HDPE } & 1 & TS & 0.992 & 0.984 & 120.691 & 0.001 & $y=-987.805+91.679$ TS \\
\hline & 2 & $T S, E$ & 0.999 & 0.999 & 39.516 & 0.001 & $y=-695.109+51.609 T S+0.886 E$ \\
\hline & 3 & TS, E, IS & 1.0 & 0.999 & 0.175 & 0.000 & $y=0.072+1.09 \mathrm{TS}+E+0.999$ IS \\
\hline \multirow{3}{*}{ LDPE } & 1 & E & 0.994 & 0.988 & 42.023 & 0.001 & $y=823.594+1.283 E$ \\
\hline & 2 & E, IS & 1.0 & 0.999 & 7.182 & 0.000 & $y=-515.742+0.973 E+1.612 I S$ \\
\hline & 3 & $E, I S, T S$ & 1.0 & 0.999 & 0.040 & 0.000 & $y=-0.973+E+1.002 I S+T S$ \\
\hline TPU & 1 & WA & 1.0 & 0.999 & 0.007 & 0.000 & $y=-1965.146+13787.6 W$ \\
\hline \multirow{2}{*}{ PA6 } & 1 & IS & 0.998 & 0.997 & 6.307 & 0.000 & $y=27.683+2.075 I S$ \\
\hline & 2 & IS, TS & 1.0 & 0.999 & 0.302 & 0.000 & $y=15.114+1.722 I S+0.94 T S$ \\
\hline PR & 1 & WA & 1.0 & 0.999 & 0.086 & 0.000 & $y=18.49+268.2 W$ \\
\hline VE & 1 & $Y M$ & 1.0 & 0.999 & 0.040 & 0.000 & $y=-2.411+25.742 Y M$ \\
\hline \multirow{2}{*}{ ER } & 1 & TS & 1.0 & 0.999 & 0.140 & 0.000 & $y=0.767+1.13 T S$ \\
\hline & 2 & $T S, E$ & 1.0 & 0.999 & 0.042 & 0.000 & $y=2.402+1.049 T S+1.075 E$ \\
\hline \multirow{2}{*}{ PUR } & 1 & TS & 1.0 & 0.999 & 0.840 & 0.000 & $y=5.981+1.115 T S$ \\
\hline & 2 & $T S, E$ & 1.0 & 0.999 & 0.023 & 0.000 & $y=5.069+1.002 T S+1.042 E$ \\
\hline
\end{tabular}

pared to the thermoset plastics. It is also noted that PA6 (447.51) scores the lowest PS on this mechanical property. This is similar to results found by Al-Oqla and Sapuan [10], where PP offered a better result for use in natural fiber reinforced composite under uncertain environments. In contrast, Mansor et al. [4] suggested that PP is the second candidate to be used for a hand-brake lever when using the analytic hierarchy process. The variation on the estimation of $P S$ is represented by the error bar plotted in Fig. 4, Fig. 5 and Fig. 6 . It indicates the uncertainty in the measured approximation values. In a recent study, the error bar was an

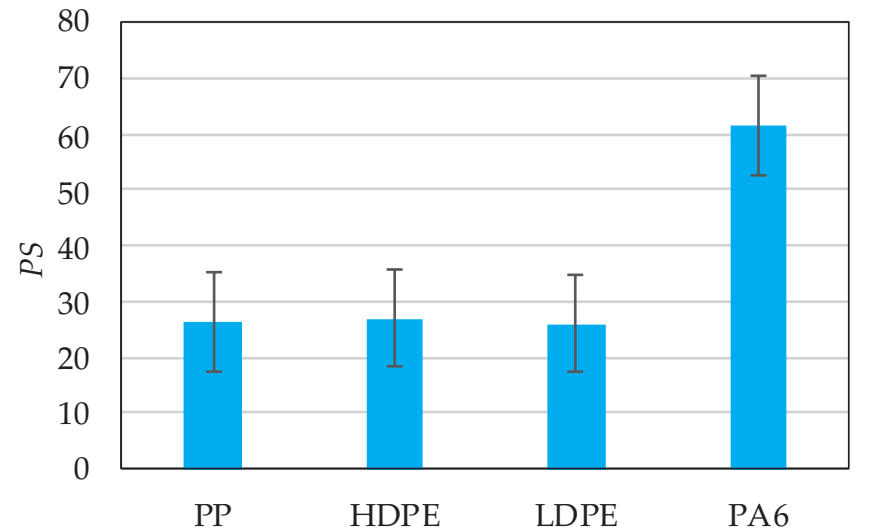

Fig. 4. The estimation of $P S$ for the alternatives with regard to impact strength (IS) informative tool to show the goodness of fit or dispersion of the data set $[55,56]$. In detail, statistical testing such as hypothesis testing, confidence interval and $t$-test should be performed to draw the final conclusion.

\section{Statistical inference on mechanical properties of $\mathrm{Tp}$ and Ts}

In this section, hypothesis testing is used as additional information to support the final decision making based on the earlier section where hypothesis testing can con-

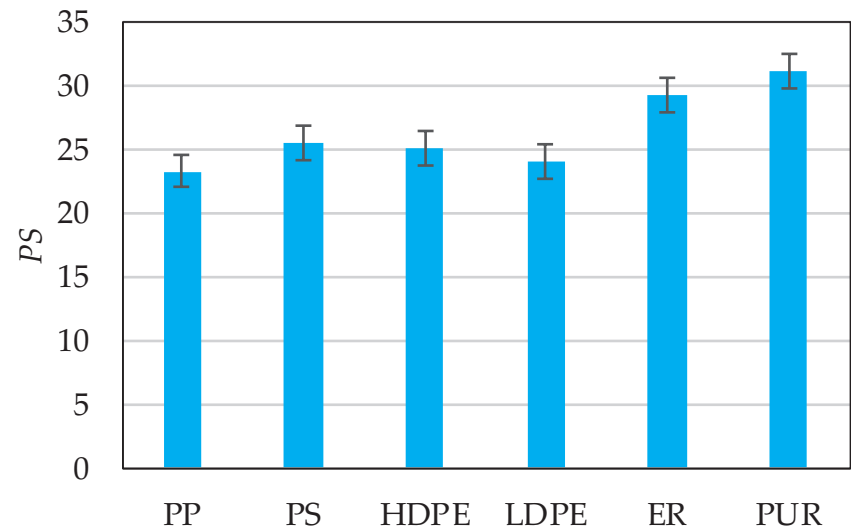

Fig. 5. The estimation of $P S$ for the alternatives with regard to elongation at break $(E)$ 


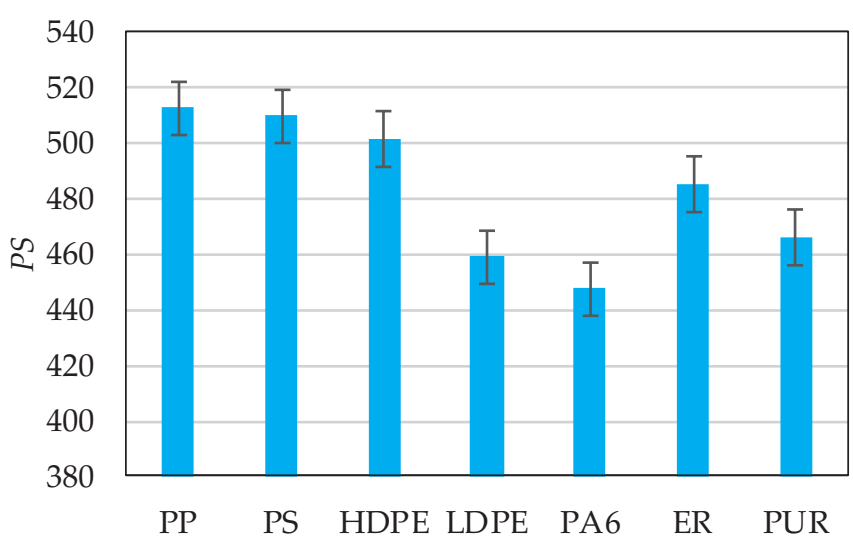

Fig. 6. The estimation of $P S$ for the alternatives with regard to tensile strength (TS)

firm the validity of prediction by using an appropriate sample to draw a conclusion in this study. Moreover, confidence interval states the accepted range with 95\% confident level on mechanical properties involved in this study. The hypothesis testing and confidence interval are performed for three selected mechanical properties, impact strength $(I S)$, elongation at break $(E)$ and tensile strength (TS). Table 3 shows the mean $(\bar{x})$, sample standard deviation (s) and number of samples $(n)$ for thermoplastic and thermoset plastic.

\section{Hypothesis testing}

Based on the result shown in Table 4, it can be concluded that Tp offers better IS value than Ts, due to insufficient evidence to reject $H_{0}$. Total energy absorbed by the material before it cracks or fails indicated the meaning of IS [57]. As the result, Tp has a higher IS compared to Ts. In this case, Tp has better ability to absorb the energy during the material's failure. This finding is con-
$\mathrm{T}$ a b l e 3. Statistical measurement of polymer for $I S, E$ and $T S$

\begin{tabular}{c|c|c|c|c}
\hline Polymer & $\begin{array}{c}\text { Statistical } \\
\text { measurement }\end{array}$ & IS & $E$ & TS \\
\hline \multirow{2}{\text{Thermoplastic,}}{} & $\bar{x}_{\mathrm{Tp}}$ & 291.121 & 305.486 & 40.736 \\
Tp & $S_{\mathrm{Tp}}$ & 378.193 & 367.019 & 17.589 \\
& $n$ & 29 & 29 & 29 \\
\hline \multirow{2}{\text{Thermoset,}}{} & $\bar{x}_{\mathrm{Ts}}$ & 167.2 & 4.415 & 64.54 \\
Ts & $s_{\mathrm{TS}}$ & 120.483 & 2.299 & 21.167 \\
& $n$ & 20 & 5 & 20 \\
\hline
\end{tabular}

sistent with the finding in previous section: IS obtained insignificant mechanical properties in statistical modelling for Ts candidates. There are no Ts candidates plotted in Fig. 5, although the hypothesis testing for $E$ concluded that the $E$ of Ts is better than that of Tp. Based on calculated $t$-test (1.811), the value fall in the critical region and over the critical point (1.697), as confirmed by tabulated $t$-test with standard error $(\alpha=0.05)$ and degree of freedom $\left(\mathrm{d} f=n_{\mathrm{Tp}}+n_{\mathrm{Ts}}-2\right)$. At this stage, the evidence to reject $H_{0}$ for $E$ hypothesis testing is sufficient. Similarly, the TS for Ts is better than that for Tp. In other words, Ts is tougher and stronger than Tp. This is due to the natural behavior of this polymer, which has a strongly crosslinked molecular structure compared to the linear structure of Tp [34, 58]. Moreover, this polymer has not melted, and so the shape of items made from it would not change if heated. Similar to Okayasu et al.[35], the tensile strength of epoxy was found to be twice as good as the other thermoplastics such as PA6 and poly(phenylene sulphide) (PPS) for carbon fiber reinforced polymer. Sivakumar et al. [45] found that the tensile strength and modulus of Ts-based material is higher than Tp-based material for a hybrid composite. In general, the mean score of TS for Ts is higher compared to that of Tp, 64.54 and 40.74, as shown in Table 4.

$\mathrm{T}$ a b 1 e 4 . Hypothesis testing between thermoplastic and thermoset plastic according to mechanical properties

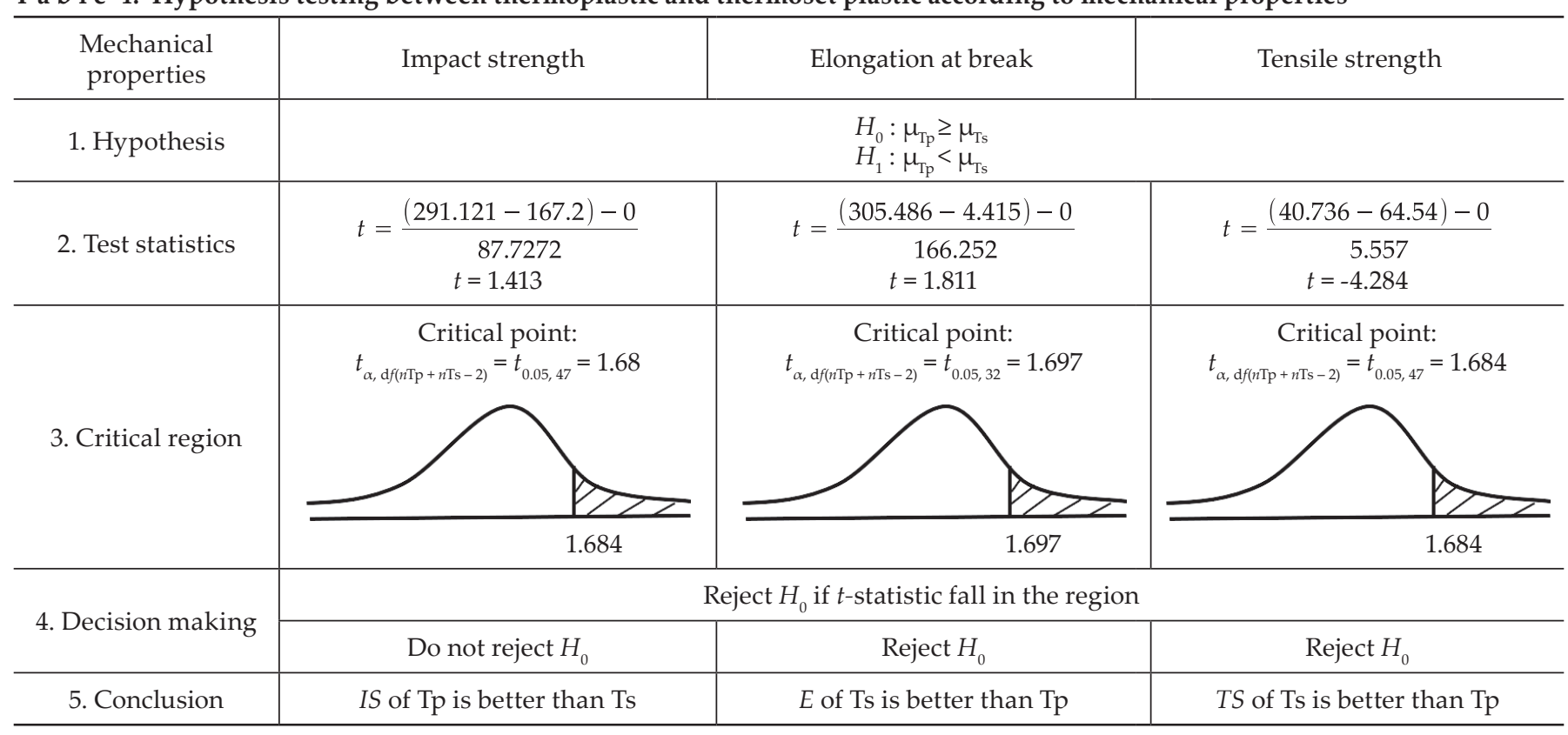




\section{Confidence interval}

Generally, confidence interval gives a range value of IS, E and TS from the data collected for Tp and Ts. Here, there is a $95 \%$ confidence interval that the value of $I S$, $E$ and TS of Tp and Ts is between (-23.81, 271.65), (18.94, $583.20)$ and $(14.45,33.16)$, respectively. By using Eq. (3) and information from Table 3, detailed calculation is shown in Table 5.

$\mathrm{T}$ a b 1 e 5. Confidence interval of mechanical properties for polymer

\begin{tabular}{c|c}
$\begin{array}{c}\text { Mechanical } \\
\text { properties }\end{array}$ & $95 \%$ confidence interval \\
\hline IS & $\begin{aligned} \mu_{I S} & =(291.121-167.2) \pm 1.684(301.79) \sqrt{\frac{1}{29}+\frac{1}{20}}= \\
& =123.921 \pm 147.732=(-23.811,271.653)\end{aligned}$ \\
$E$ & $\begin{aligned} \mu_{E} & =(305.486-4.415) \pm 1.697(343.316) \sqrt{\frac{1}{29}+\frac{1}{5}}= \\
& =301.071 \pm 282.129=(18.941,583.200)\end{aligned}$ \\
$T S$ & $=23.804 \pm 9.358=(14.446,33.162)$
\end{tabular}

Overall, $95 \%$ of the general impact strength of the polymer is distributed between $-23.811 \mathrm{~J} / \mathrm{m}^{2}$ and $271.653 \mathrm{~J} / \mathrm{m}^{2}$. In this case, zero impact to $271.653 \mathrm{~J} / \mathrm{m}^{2}$ are the range of the impact strength of polymer are distributed. For elongation at break, the distribution is between $18.941 \%$ and $583.200 \%$ and, lastly, with the same confidence interval, which is $95 \%$ of the tensile strength, the distribution is between $14.446 \mathrm{MPa}$ and $33.162 \mathrm{MPa}$.

\section{CONCLUSIONS}

The evaluation of mechanical properties for 10 types of polymer in material selection by using statistical modelling was successfully achieved in this work. Additional information from statistical measurement such as estimation, hypothesis testing and confidence interval in this study was used to demonstrate the material's performance effectively for each candidate throughout the polymer selection process. It can be concluded here that proper selection of polymers is dependent on mechanical properties that influence the statistical modelling for estimation, hypothesis testing and confidence interval. This work can act as a guideline for the selection of the most suitable polymer candidate for an engineering application. The results showed that:

- hypothesis testing and confidence interval results achieved a good agreement with the theory of thermoset and thermoplastic materials and this led to the final decision making on material selection;
- impact strength, elongation at break and tensile strength of the polymer were the three most important mechanical properties shown by the statistical modelling;

- the most suitable candidates to manufacture the hand-brake lever are PA6 if based on impact strength, PUR on elongation at break and PP on tensile strength;

- thermoset plastic offers better results than thermoplastic for tensile strength and elongation at break, whereas thermoplastic exhibits better impact strength than thermoset.

\section{ACKNOWLEDGMENTS}

The authors would like to thank Universiti Putra Malaysia for the opportunity to conduct this study as well as Universiti Teknikal Malaysia Melaka and the Ministry of Education of Malaysia for providing the scholarship award and grant scheme Hi-COE (6369107) to the principal author in this project.

\section{REFERENCES}

[1] Furtado S.C.R., Araújo A.L., Silva A. et al.: International Journal of Automotive Composites 2014, 1, 18. http://dx.doi.org/10.1504/IJAUTOC.2014.064112

[2] Hambali A., Sapuan S.M., Ismail N., Nukman Y.: Journal of Central South University of Technology 2010, $17,244$. http://dx.doi.org/10.1007/s11771-010-0038-y

[3] Ishak N.M., Malingam S.D., Mansor M.R.: International Journal of Materials and Product Technology 2016, 53, 267. http://dx.doi.org/10.1504/IJMPT.2016.079205

[4] Mansor M.R., Hambali A., Azaman M.D. et al.: International Symposium on the Analytic Hierarchy Process 2013, pp. 1-8. http://dx.doi.org/10.13033/isahp.y2013.053

[5] Mastura M.T., Sapuan S.M., Mansor M.R., Nuraini A.A.: The International Journal of Advanced Manufacturing Technology 2017, 89, 2203. http://dx.doi.org/10.1007/s00170-016-9217-9

[6] Mayyas A., Shen Q., Mayyas A. et al:: Materials and Design 2011, 32, 2771.

http://dx.doi.org/10.1016/j.matdes.2011.01.001

[7] Sapuan S.M.: Assembly Automation 2005, 25, 146. http://dx.doi.org/10.1108/01445150510590514

[8] Aghajani Mir M., Taherei G.P., Sulaiman N.M.N. et al.: Journal of Environmental Management 2016, 166, 109. http://dx.doi.org/10.1016/j.jenvman.2015.09.028

[9] Al-Oqla F.M., Sapuan S.M., Ishak M.R., Nuraini A.A.: Journal of Composite Materials 2015, 50, 543. http://dx.doi.org/10.1177/0021998315577233

[10] AL-Oqla F.M., Sapuan S.M.: The Journal of The Minerals, Metals \& Materials Society 2015, 67, 2450. http://dx.doi.org/10.1007/s11837-015-1548-8

[11] Altay L., Atagur M., Akyuz O. et al.: Polymer Composites 2017, 39, 1.

[12] Sahari J., Sapuan S.M., Zainudin E.S., Maleque M.A.: Materials and Design 2013, 49, 285.

http://dx.doi.org/10.1016/j.matdes.2013.01.048 
[13] Verrey J., Wakeman M.D., Michaud V., Månson J.A.E.: Composites Part A: Applied Science and Manufacturing 2006, 37, 9. http://dx.doi.org/10.1016/j.compositesa.2005.05.048

[14] Jumaidin R., Sapuan S.M., Jawaid M., Ishak M.R.: International Journal of Biological Macromolecules 2017, 97, 606. http://dx.doi.org/10.1016/j.ijbiomac.2017.01.079

[15] Bienias B., Michalski W., Wagner L.: Polimery 2019, $64,417$. http://dx.doi.org/10.14314/polimery.2019.6.4

[16] Amel B.A., Paridah M.T., Sudin R. et al.: Industrial Crops and Products 2013, 46, 117. http://dx.doi.org/10.1016/j.indcrop.2012.12.015

[17] Gurunathan T., Mohanty S., Nayak S.K.: Composites Part A: Applied Science and Manufacturing 2015, 77, 1. http://dx.doi.org/10.1016/j.compositesa.2015.06.007

[18] Zhao Y.W., Gu Y.Z., Huang P.: Polymer Composites 2017, 39, 1.

[19] Ilyas R.A., Sapuan S.M., Ishak M.R., Zainudin E.S.: Carbohydrate Polymers 2018, 202, 186. http://dx.doi.org/10.1016/j.carbpol.2018.09.002

[20] Calado E.A., Leite M., Silva A.: Journal of Cleaner Production 2018, 186, 113. http://dx.doi.org/10.1016/j.jclepro.2018.02.048

[21] Lyu M.Y., Choi T.G.: International Journal of Precision Engineering and Manufacturing 2015, 16, 213. http://dx.doi.org/10.1007/s12541-015-0029-x

[22] Azammi A.M.N., Sapuan S.M., Ishak M.R., Sultan M.T.H.: Fibers and Polymers 2018, 19, 446.

[23] Radzi A.M., Sapuan S.M., Jawaid M., Mansor M.R.: Fibers and Polymers 2017, 18, 1353. http://dx.doi.org/10.1007/s12221-017-7311-8

[24] Väisänen T., Das O., Tomppo L.: Journal of Cleaner Production 2017, 149, 582.

[25] Ilyas R.A., Sapuan S.M., Ishak M.R., Zainudin E.S.: International Journal of Biological Macromolecules 2019, $123,379$.

[26] Punyamurthy R., Sampathkumar D.: International Journal of Sciences: Basic and Applied Research 2014, 18, 305.

[27] Rajesh M., Pitchaimani J., Rajini N.: Procedia Engineering 2016, 144, 1055. http://dx.doi.org/10.1016/j.proeng.2016.05.056

[28] Hufenbach W., Gude M., Geller S., Czulak A.: Polimery 2013, 58, 473. http://dx.doi.org/10.14314/polimery.2013.473

[29] Salasinska K., Polka M., Gloc M., Ryszkowska J.: Polimery 2016, 61, 255.

http://dx.doi.org/10.14314/polimery.2016.255

[30] Peters E.N.: "Thermoplastics, Thermosets, and Elastomers - Descriptions and Properties" in "Mechanical Engineers' Handbook" 4th ed. (Ed. Kutz M.), John Wiley \& Sons Inc, Selkirk, New York 2015.

[31] Abishera R., Velmurugan R., Nagendra Gopal K.V.: Polymer Engineering Science 2018, 58, 189. http://dx.doi.org/10.1002/pen.24861
[32] Singh A.K., Panda B.P., Mohanty S. et al.: PolymerPlastics Technology and Engineering 2018, 57, 903. http://dx.doi.org/10.1080/03602559.2017.1354253

[33] Tatsuno D., Yoneyama T., Kawamoto K., Okamoto M.: Polymer Composites 2016, 39, 2571. http://dx.doi.org/10.1002/pc. 24242

[34] Chung D.D.L.: Materials Science and Engineering: R: Reports 2017, 113, 1. http://dx.doi.org/10.1016/j.mser.2017.01.002

[35] Okayasu M., Tsuchiya Y., Arai H.: Journal of Materials Science Research 2018, 7, 12. http://dx.doi.org/10.5539/jmsr.v7n3p12

[36] Velasquez M., Hester P.T.: International Journal of Operations Research 2013, 10, 56.

[37] Shah D.U.: Materials and Design 2014, 62, 21. http://dx.doi.org/10.1016/j.matdes.2014.05.002

[38] Ahmed Ali B.A., Sapuan S.M., Zainudin E.S., Othman M.: Journal of Cleaner Production 2015, 107, 557. http://dx.doi.org/10.1016/j.jclepro.2015.05.084

[39] Das A., Kumar A.: Journal of Mechanical and Civil Engineering 2015, 12, 82.

[40] Noryani M., Sapuan S.M., Mastura M.T. et al.: Fibers and Polymers 2018, 19, 1039. http://dx.doi.org/10.1007/s12221-018-8113-3

[41] Noryani M., Sapuan S.M., Mastura M.T. et al.: Journal of Materials Research and Technology 2019, 8, 2865. http://dx.doi.org/10.1016/j.jmrt.2019.02.019

[42] Yousefpour M., Rahimi A.: Materials and Design 2014, $54,382$. http://dx.doi.org/10.1016/j.matdes.2013.08.017

[43] "Granta Design, CES Edupack" 2013.

[44] Mastura M.T., Sapuan S.M., Mansor M.R., Nuraini A.A.: International Journal of Precision Engineering and Manufacturing-Green Technology 2017, 5, 111. http://dx.doi.org/10.1007/s40684-018-0012-y

[45] Sivakumar D., Ng L.F., Lau S.M., Lim K.T.: J.ournal of Polymer Environment 2017, 26, 499. http://dx.doi.org/10.1007/s10924-017-0970-0

[46] Stirna U., Beverte I., Yakushin V., Cabulis U.: Journal of Cellular Plastics 2011, 47, 337. http://dx.doi.org/10.1177/0021955X11398381

[47] Mansor M.R., Sapuan S.M., Zainudin E.S. et al.: Materials and Design 2013, 51, 484. http://dx.doi.org/10.1016/j.matdes.2013.04.072

[48] Patel M.V., Sarawade S.S.: "Design and Weight Optimization of Parking Brake Lever" in $3^{\text {rd }}$ International Conference on Emerging Trends in Engineering and Management Research, Pune, India, July 30, 2017, p. 367.

[49] Fayazbakhsh K., Abedian A., Manshadi B.D., Khabbaz R.S.: Materials and Design 2009, 30, 4396. http://dx.doi.org/10.1016/j.matdes.2009.04.004

[50] Linul E., Marsavina L., Voiconi T., Sadowski T.: Journal of Physics: Conference Series 2013, 451, 1. http://dx.doi.org/10.1088/1742-6596/451/1/012002

[51] Van de Velde K., Kiekens P.: Composite Structures 2001, 54, 355 . 
[52] Noryani M., Sapuan S.M., Mastura M.T. et al.: "Stepwise regression for kenaf reinforced polypropylene composite" in $5^{\text {th }}$ Mechanical Engineering Research Day 2018, Melaka, Malaysia, May 3, 2018, p. 48.

[53] Peponi L., Biagiotti J., Torre L. et al.: Polymer Composites 2008, 29, 313. https://doi.org/10.1002/pc.20408

[54] Chung K.F., Chiew S.P., Lee H.Y.: "Selection of Equivalent Steel Materials to European Steel Materials Specifications", Hong Kong Constructional Metal Structures Association, Hong Kong 2015.

[55] Priya I.I.M., Vinayagam B.K.: International Journal of Polymer Science 2018, ID 8629894. https://doi.org/10.1155/2018/8629894

[56] Selamat M.Z., Syazwan M., Tahir Z. et al.: "Effect of starch sizes particle as binder on short pineapple leaf fiber composite mechanical properties" in MATEC Web of Conferences 2018, 150, 04008, MUCET 2017 Malaysia. http://dx.doi.org/10.1051/matecconf/201815004008

[57] Nadlene R., Sapuan S.M., Jawaid M. et al.: BioResources 2016, 11, 9325.

[58] Sapuan S.M.: "Composite Materials" in "Composite Materials" 1st ed. (Ed. Sapuan S.M.), ButterworthHeinemann: Elsevier Inc., 2017, pp. 57-93. http://dx.doi.org/10.1016/B978-0-12-802507-9.00003-9

Received 26 VI 2019

Serdecznie zapraszamy pracowników uczelni, instytutów badawczych i przemysłu do udziału w

\section{Konferencji Naukowo-Technicznej „Kierunki Modyfikacji i Zastosowań Tworzyw Polimerowych"} połączonej z XXII Warsztatami Profesorskimi, która odbędzie się w dniach 25-27 maja 2020 r. w Centrum Postępu Technicznego SIMP w zamku w Rydzynie k. Leszna.

Celem spotkania jest prezentacja i dyskusja naukowa dotycząca przetwórstwa tworzyw polimerowych, ich modyfikacji, metod oceny właściwości oraz nowych zastosowań, a także możliwości współpracy z przemysłem. Wzorem spotkania w 2019 roku (Polimery 2019, 10, 705), planowana jest szeroka dyskusja z udziałem przedstawicieli przemysłu na temat gospodarki tworzywami polimerowymi w obiegu zamkniętym.

Przewodniczący konferencji:

Prof. dr hab. inż. Tomasz Sterzyński

Sprawy organizacyjne:

Dr inż. Monika Knitter - monika.knitter@put.poznan.pl, tel. 61 665-28-94

Dr inż. Monika Dobrzyńska-Mizera - monika.dobrzynska-mizera@put.poznan.pl, tel. 61 665-28-94

Biuro Organizacyjne: DIVISIA www.divisia.pl 